\title{
Daily temperature profiles in and around Western Kenyan larval habitats of Anopheles gambiae as related to egg mortality Juan Huang1, Edward D Walker ${ }^{1,2}$, John Vulule ${ }^{3}$ and James R Miller*1
}

\author{
Address: ${ }^{1}$ Department of Entomology, Michigan State University, East Lansing, MI 48824, USA, ${ }^{2}$ Microbiology and Molecular Genetics, Michigan \\ State University, East Lansing, MI 48824, USA and ${ }^{3}$ Kenya Medical Research Institute, Kisumu, Kenya \\ Email: Juan Huang - huangju@msu.edu; Edward D Walker - walker@msu.edu; John Vulule - jvulule@kisian.mimcom.net; \\ James R Miller* - miller20@msu.edu \\ * Corresponding author
}

Published: 12 October 2006

Malaria Journal 2006, 5:87 doi:10.1186/1475-2875-5-87

This article is available from: http://www.malariajournal.com/content/5/I/87

(C) 2006 Huang et al; licensee BioMed Central Ltd.

This is an Open Access article distributed under the terms of the Creative Commons Attribution License (http://creativecommons.org/licenses/by/2.0), which permits unrestricted use, distribution, and reproduction in any medium, provided the original work is properly cited.
Received: 06 June 2006

Accepted: 12 October 2006

\begin{abstract}
Background: Anopheles gambiae eggs are more frequently found on soil around puddle habitats of the larvae, than on the water surface itself in Western Kenya. Thus, eggs can experience temperatures more wide-ranging and lethal than those experienced by larvae or pupae confined within puddles.

Methods: Small batches of eggs from house-collected An. gambiae as well as from the Kisumu laboratory strain were bathed for defined times in water whose temperature was precisely controlled. Daily temperature profiles were recorded by an infrared thermometer on seven different days in and around three types of typical An. gambiae larval habitats at Kisian.

Results: For wild eggs, significant mortality occurred upon brief heating between $42-44^{\circ} \mathrm{C}$. Few eggs hatched after $10 \mathrm{~min}$ at $45^{\circ} \mathrm{C}$ and none hatched above this temperature. A similar pattern occurred for eggs of the Kisumu strain, except it was shifted downwards by $\mathrm{I}^{\circ} \mathrm{C}$. Egg mortality was time-dependent above $40^{\circ} \mathrm{C}$. Temperatures of water in the three types of larval habitats never exceeded $35^{\circ} \mathrm{C}$. Wet or damp mud rarely and only briefly exceeded $40^{\circ} \mathrm{C}$; thus, water and mud would be highly conducive to egg survival and development. However, dry soils frequently reached $40-50^{\circ} \mathrm{C}$ for several h. Eggs stranded on dry surfaces would experience substantial mortality on hot, sunny days.
\end{abstract}

Conclusion: Moist mud around puddles constitutes suitable habitat for An. gambiae eggs; however, eggs on the surface of dry soil under direct sunlight are unlikely to survive for more than a few hours.

\section{Background}

Malaria infects 300-500 million people each year [1]. More than $90 \%$ of malarial cases occur in Sub-Saharan Africa, where Anopheles gambiae is the principal vector. Despite the high vectorial capacity of this mosquito, critical aspects of its biology bearing on population dynamics and ultimately malaria transmission remain to be eluci- dated. For example, little is known about how abiotic factors like temperature influence egg survival. Eggs of $A n$. gambiae are more frequently found on mud (soil) around puddle habitats of the larvae than on the water surface itself [2]. Larvae developing and hatching on wet substrates like mud [3] can crawl to puddles $[2,4]$ or perhaps be washed there by rains [2]. It is also not uncommon for 
puddles and the mud around them to desiccate. Thus, eggs can experience temperature regimes more wide-ranging and lethal than temperatures experienced by larvae or pupae in puddles.

Some research has been conducted on tolerance of $A n$. gambiae eggs to desiccation. Unlike some mosquitoes, e.g., Aedes and Ochlerotatus, eggs of An. gambiae cannot tolerate prolonged desiccation [5]. Survivorship of An. gambiae eggs in drying soils held in the laboratory was found to be inversely related to time after deposition; very few eggs in drying soils hatched after 12 to 15 days upon reflooded [6]. It has been suggested that the egg stage of An. gambiae might contribute to the short-term survival of this vector during dry periods [6]. However, these studies did not consider temperatures likely to be encountered when soils dry under natural, out-door conditions likely to be sunny.

The effects of temperature on embryonic development and egg hatching of An. gambiae have received little attention. In contrast, considerable data are available for other mosquitoes and insects generally [7-11]. Upper tolerable temperatures for eggs in these studies ranged from 33 to $48^{\circ} \mathrm{C}$.

Growth, development, and survival of An. gambiae as influenced by constant temperatures between 10 and $40^{\circ} \mathrm{C}$ have been analyzed under laboratory conditions [12]. The optimal temperature for larval growth was $28^{\circ} \mathrm{C}$, while maximal fitness of adults occurred between 28 and $32^{\circ} \mathrm{C}$. Growth and development of instars 1-4 and pupae ceased at $40,38,36,34$, and $34^{\circ} \mathrm{C}$, respectively, under constant temperature regimes [12]. However, the ability of An. gambiae eggs to withstand temperatures of $40^{\circ} \mathrm{C}$ and greater was not reported, nor was the effect of fluctuating temperatures evaluated.

The objectives of the current study were to: 1) establish lethal temperatures for An. gambiae eggs briefly exposed to elevated temperatures, and 2) determine whether and for how long eggs located in and around typical An. gambiae larval habitats would be exposed to damaging temperatures during the long rainy season in Kisumu, Kenya.

\section{Materials and methods}

\section{Mosquitoes and bioassay conditions}

Experiments were performed using eggs from two sources: feral females of the An. gambiae complex aspirated from houses near Kisian, Kenya between 15 April and 15 May 2005, and the Kisumu laboratory strain (An. gambiae s. s.) originating from the Kenyan Medical Research Institute (KEMRI) located near Kisumu. Eggs used were laid overnight and were 9-20 h old by the time of heat treatment. After oviposition, samples of randomly selected females were removed from each cage and placed into individual $1.5 \mathrm{~mL}$ centrifuge tubes, air-dried under silica for 3 days, and stored at $4{ }^{\circ} \mathrm{C}$ for species identification within the $A n$. gambiae complex by PCR using the methods of Scott et al. [13]. Seventy five individuals were tested.

\section{Egg survival in response to temperature and exposure times}

Published heating methods for mosquito eggs have employed water baths [8], incubators [14], or specially designed devices [15]. Here, a thermal cycler, normally used for polymerase chain reaction, was used as a rapid and precise heating device. Between 50 to 100 randomly selected eggs from an ovipositional dish receiving several thousand eggs of a given An. gambiae population were carefully transferred by a fine brush into $40 \mu \mathrm{l}$ of water in a $0.2 \mathrm{ml}$ PCR tube (Dot Scientific Incorporated, Burton, MI, USA). Tubes were heated for $10 \mathrm{~min}$ in a Thermal Cycler (GeneAmp PCR System 9700, Applied Biosystems, Foster City, CA, USA) to 40,41, 42, 43, 44, 45, 46, 47, or $48^{\circ} \mathrm{C}$. Control batches of eggs were also transferred into PCR tubes, but not heated. These PCR tubes were kept at the room temperature $\left(22^{\circ} \mathrm{C}\right)$ while the other groups of eggs were being heated. Treated and control eggs were transferred into 9-cm diameter Petri dishes with $30 \mathrm{ml}$ water; exact numbers of eggs in each Petri dish were then counted. Numbers of emerged larvae were recorded every day at $25^{\circ} \mathrm{C}$ until eggs were $7 \mathrm{~d}$ old. Pilot tests had revealed no hatch for any treatments beyond $7 \mathrm{~d}$. In each run of the experiment, three replicates were performed on each of the 10 total temperatures. The whole procedure was repeated another two times using different batches of eggs.

Eggs of the Kisumu laboratory strain were heated at 40 , 41,42 , or $43^{\circ} \mathrm{C}$ for $10-160 \mathrm{~min}$ (depending on temperature) to record egg mortality as influenced by the exposure times indicated in Figure 3. Thereafter, eggs were handled as above. Each time point was replicated three times using a given batch of eggs. This procedure was then twice repeated using different batches of eggs.

\section{Daily temperature profiles in and around Anopheles gambiae larval habitats}

Three typical types of An. gambiae larval habitats [16] were selected just outside the KEMRI campus in Kisian: puddle in a maize drainage ditch, puddle in a roadway, and a burrow pit. Daily temperature profiles in and around these larval habitats (Figure 1) were monitored once each $\mathrm{h}$ from 8:00 to $18: 00 \mathrm{~h}$ by a hand-held infrared thermometer (Model IRT4, Spectrum Technologies, Inc., Plainfield, IL, USA) for $7 \mathrm{~d}$ between 27 April to 12 May, 2005, the long rainy season when An. gambiae population peaks. Since the burrow pit was surrounded by grasses, no unshaded dry soil was available. However, temperatures of a 


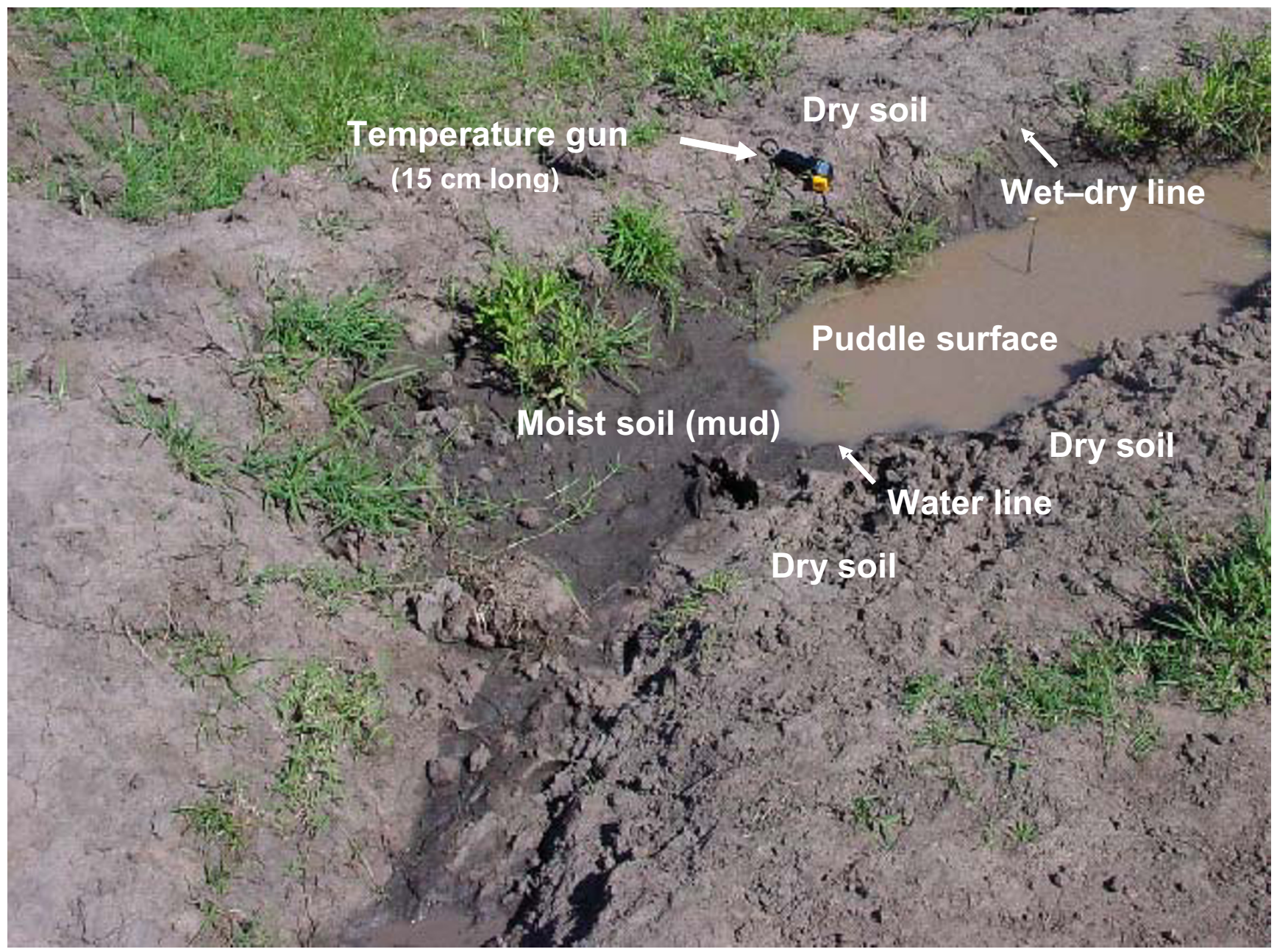

Figure I

Picture of an Anopheles gambiae larval habitat in a maize drainage ditch showing differentiation of zones where temperatures were monitored. The shift from wet or damp mud to dry soil was abrupt and accompanied by a shift from black to gray.

rock (ca. $40 \mathrm{~cm}$-diameter) at the edge of this burrow pit were included.

\section{Statistical analysis}

Mean egg survival after exposure to the 10 constant temperatures was compared using 1-way analysis of variance (ANOVA) on data transformed by arcsine of the square root [17]. Mean separations were performed by Tukey's significant difference (HSD). The effect of exposure times on egg survival was analyzed by linear regression.

\section{Results}

\section{Egg survival in response to temperature and exposure}

\section{times}

Of 75 house-collected mosquitoes identified by PCR, 71 were An. gambiae s. s., two were Anopheles arabiensis, and two were unknown. Therefore, eggs used in this study were overwhelmingly An. gambiae s. s. These eggs were tolerant of brief exposures of temperatures up to $44^{\circ} \mathrm{C}$ (Figure 2). Emergence of larvae after exposure to $42^{\circ} \mathrm{C}$ was significantly lower $(\mathrm{F}=94 ; \mathrm{df}=9,80 ; \mathrm{P}<0.001)$ than for control eggs from house-collected females. Eclosion dramatically decreased from over $50 \%$ to $12 \%$ with a temperature rise from $44-45^{\circ} \mathrm{C}$. No eggs exposed to $46^{\circ} \mathrm{C}$ for 10 min hatched (Figure 2A). An identical pattern, but shifted $1{ }^{\circ} \mathrm{C}$ lower, was recorded for eggs of the Kisumu laboratory strain (Figure 2B).

The survival of An. gambiae eggs at elevated temperatures was also influenced by exposure time (Figure 3 ). At given temperatures of 41,42 , and $43^{\circ} \mathrm{C}$, the numbers of Kisumu eggs that hatched decreased linearly with exposure times $\left(41^{\circ} \mathrm{C}: \mathrm{F}=49.0 ; \mathrm{df}=1,7 ; \mathrm{P}<0.001 ; 42^{\circ} \mathrm{C}: \mathrm{F}=134.6 ; \mathrm{df}\right.$ $\left.=1,9 ; \mathrm{P}<0.001 ; 43^{\circ} \mathrm{C}: \mathrm{F}=396.8 ; \mathrm{df}=1,4 ; \mathrm{P}<0.001\right)$. 


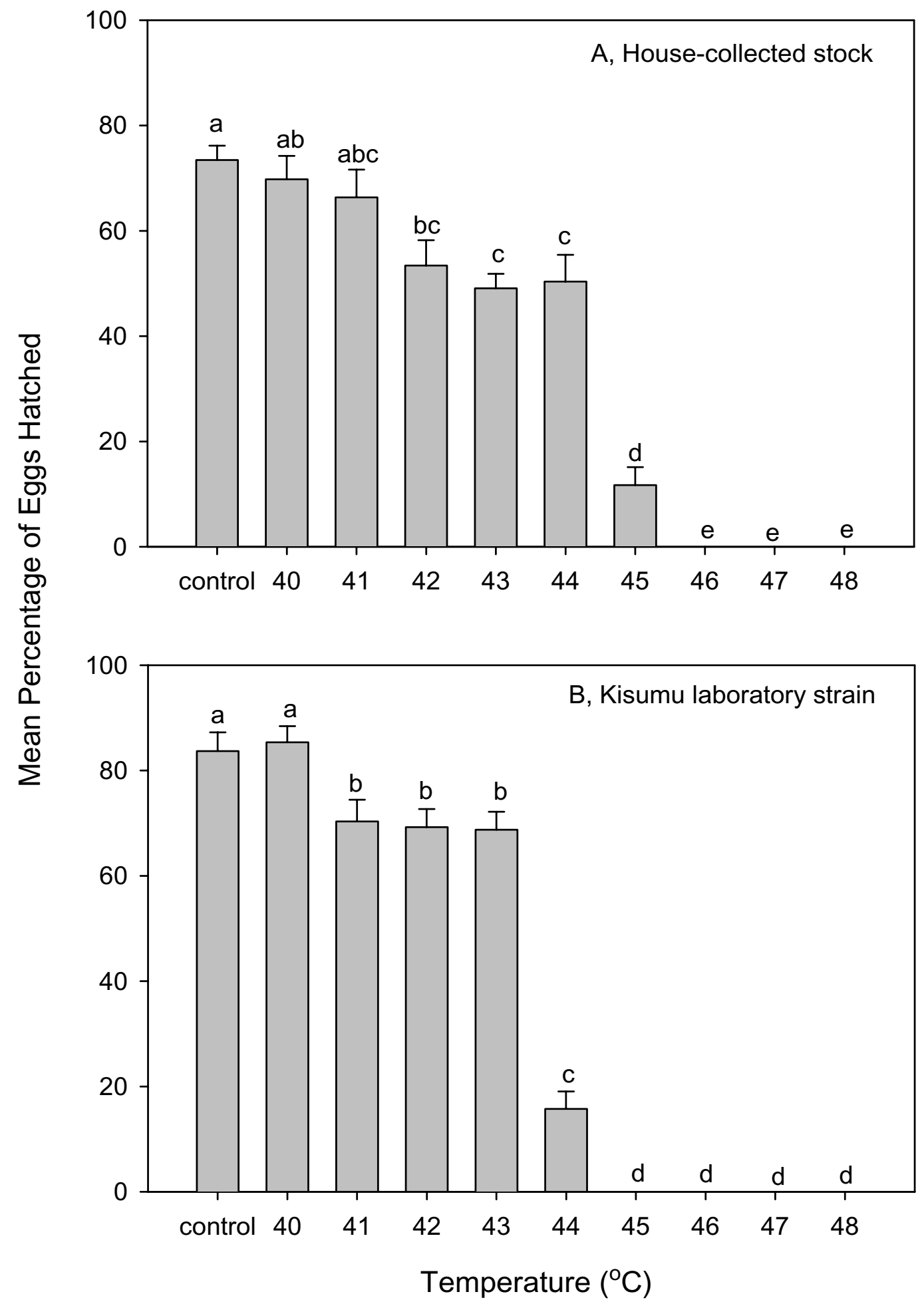

Figure 2

Larval eclosion from two populations of Anopheles gambiae eggs as influenced by 10 min of exposure to elevated temperatures. Error bars $=S$. E. M. 


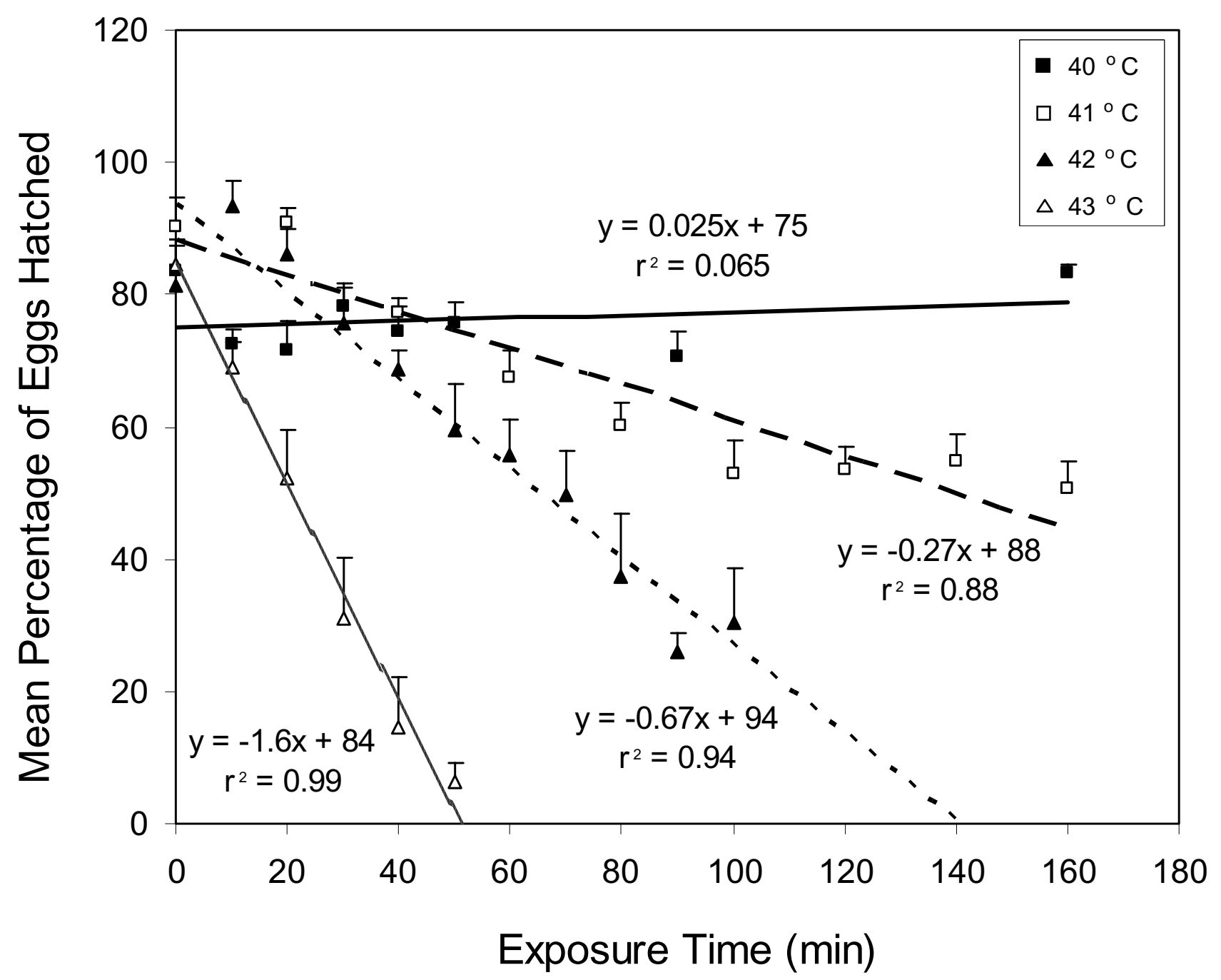

Figure 3

The relationship between egg hatch and exposure times for Anopheles gambiae eggs heated at 40, 4 I, 42, or $43^{\circ} \mathrm{C}$. Error bars $=$ S. E. M.

The lethal time for 50\% kill $\left(\mathrm{LT}_{50}\right)$ of eggs decreased from 126 to $20 \mathrm{~min}$ as exposure temperature increased from 41 to $43^{\circ} \mathrm{C}$. However, no such pattern was observed at $40^{\circ} \mathrm{C}$, where egg hatch was not significantly affected by exposure time up to $160 \mathrm{~min}(\mathrm{~F}=0.4 ; \mathrm{df}=1,6 ; \mathrm{P}=0.5)$.

Egg survivorship appeared to diminish exponentially rather than linearly with increasing temperatures above $40^{\circ} \mathrm{C}$. An exponential (logarithmic) relationship between temperature $>40^{\circ} \mathrm{C}$ and survivorship per minute of exposure at a given temperature was confirmed by Figure 4 ( F $=183.7 ; \mathrm{df}=1,37 ; \mathrm{P}<0.001)$. Moreover, these data yielded a general equation $\left(\log _{10} \%\right.$ mortality $/ \mathrm{min}=$ $\left.0.35\left({ }^{\circ} \mathrm{C}\right)-15\right)$ permitting the calculation of egg mortality expected for various combinations of temperatures and times (Table 1).

\section{Daily temperature profiles in and around Anopheles gambiae larval habitats}

Similar daily temperature profiles were recorded in and around the three types of larval habitats on each of the three consecutive sunny days shown in Figure 5. As expected, the maximum daily temperature occurred between 13:00-16:00 h. Soil temperatures rarely exceeded the upper tolerable temperature for An. gambiae eggs of $40^{\circ} \mathrm{C}$, except where soils became dry to the touch and grey rather than black (Table 2). On sunny days, dry soils around habitats were very likely to exceed $41^{\circ} \mathrm{C}$ for 


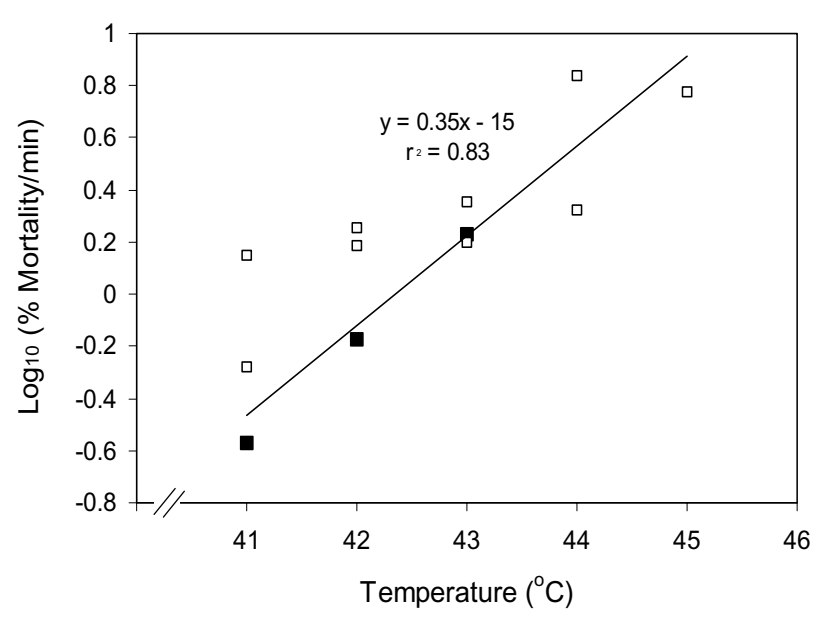

Figure 4

Linear relationships between temperatures above $40^{\circ} \mathrm{C}$ and $\log _{10} \%$ mortality/min for eggs of Anopheles gambiae. Data denoted by filled squares are the slopes from Figure 3; data denoted by open squares were calculated from Figure 2, based on mortality per $10 \mathrm{~min}$ for house-collected stock and Kisumu laboratory strain. \% mortality/min for the open squares $=$ (mean survivorship in control - mean survivorship in each treatment) $/ 10 \mathrm{~min}$. Because each slope from Figure 3 was a composite derived from 10 original data, these points (filled squares) were weighted $10 x$ in a weighted regression analysis.

an average of $4 \mathrm{~h}$ (Table 2). Temperatures at the water line and on wet or damp mud were little higher than the temperatures of puddle water.

\section{Discussion}

It is well known that insect embryogenesis and egg hatching are influenced by temperature [10]. There are definite thresholds below or above which no eggs hatch. For example, all the embryos of Culex theileri died after eggs were incubated at a constant temperature between 39 to $42^{\circ} \mathrm{C}[11]$. Exposure of eggs of Culex quinquefasciatus for $24 \mathrm{~h}$ at $39^{\circ} \mathrm{C}$ completely inhibited egg hatch [10]. All eggs of Aedes structys exposed to a constant $33^{\circ} \mathrm{C}$ failed to hatch [9]. No larvae emerged after Anopheles sergentii eggs were incubated at $34^{\circ} \mathrm{C} \mathrm{[18].} \mathrm{The} \mathrm{upper} \mathrm{tolerable} \mathrm{temperatures}$ for egg development and hatching of other insects were: 46 to $48^{\circ} \mathrm{C}$ for the tephritid fruit fly, Bactrocera latifrons [19]; $42^{\circ} \mathrm{C}$ for the Queensland fruit fly, Bactrocera tryoni [8]; $39^{\circ} \mathrm{C}$ for the common cattle grub, Hypoderma lineatum [20]; $37^{\circ} \mathrm{C}$ for the reindeer warble fly, Hypoderma tarandi [21]; and $32^{\circ} \mathrm{C}$ for the Diaprepes root weevil, Diaprepes abbreviatus [7].

Survival of An. gambiae eggs was strongly influenced both by temperature and exposure times (Figure 3; Table 1). The upper tolerable temperature for these eggs was $40^{\circ} \mathrm{C}$. Above this threshold, the rate of egg kill was approximately linear over time for a given temperature (Figure 3). Estimated $\mathrm{LT}_{50}$ values for the following temperatures were: $41^{\circ} \mathrm{C}-147 \mathrm{~min} ; 42^{\circ} \mathrm{C}-66 \mathrm{~min} ; 43^{\circ} \mathrm{C}-30 \mathrm{~min}$; $44^{\circ} \mathrm{C}-14 \mathrm{~min} ; 45^{\circ} \mathrm{C}-6 \mathrm{~min}$; and $46^{\circ} \mathrm{C}-2.8 \mathrm{~min}$ (based on the equation from Figure 4$)$. Thus, for each successive degree temperature rose beyond $41^{\circ} \mathrm{C}$, the time required for $50 \%$ egg kill was approximately halved. Stated conversely, the velocity of some time-dependent process killing eggs approximately doubled with each rise of one degree $\mathrm{C}$.

Protein denaturation [22] is a likely mechanism explaining this pattern of lethality. Nguyen et al. [24] quantified the time-course for denaturation of a firefly luciferase and an Escherichia coli $\beta$-galactosidase transfected into Drosophila and mouse cell lines. Denaturation was detectable at $37^{\circ} \mathrm{C}$, but with a half-life of more than three h. Incubation of these cells at $42^{\circ} \mathrm{C}$ yielded approximately linear protein degradation profiles with half-lives ranging from 5-40 min depending upon experimental conditions.

Table I: Predicted mortality of Anopheles gambiae eggs exposed to various combinations of temperature and time, as calculated from the regression equation of Figure 4.

\begin{tabular}{|c|c|c|c|c|c|c|}
\hline \multirow[b]{2}{*}{ Time (min) } & \multicolumn{6}{|c|}{ Predicted \% Egg Mortality } \\
\hline & $41^{\circ} \mathrm{C}$ & $42^{\circ} \mathrm{C}$ & $43^{\circ} \mathrm{C}$ & $44^{\circ} \mathrm{C}$ & $45^{\circ} \mathrm{C}$ & $46^{\circ} \mathrm{C}$ \\
\hline 1 & 0.3 & 0.8 & 2 & 4 & 8 & 18 \\
\hline 2 & 0.7 & 2 & 3 & 7 & 16 & 36 \\
\hline 4 & 1 & 3 & 7 & 15 & 33 & 73 \\
\hline 8 & 3 & 6 & 13 & 30 & 66 & 100 \\
\hline 14 & 5 & 11 & 23 & 52 & 100 & \\
\hline 20 & 7 & 15 & 33 & 74 & & \\
\hline 30 & 10 & 23 & 50 & 100 & & \\
\hline 60 & 20 & 45 & 100 & & & \\
\hline 120 & 41 & 90 & & & & \\
\hline 180 & 61 & 100 & & & & \\
\hline 300 & 100 & & & & & \\
\hline
\end{tabular}


Table 2: Frequency and duration of potentially lethal thermal events in and around Anopheles gambiae larval habitats between 27 April and 12 May, 2005 at Kisian, Kenya.

\begin{tabular}{lccc}
\hline Location & Total events of $41^{\circ} \mathrm{C}$ or greater & Daily events per habitat & Mean duration per event $(\mathrm{h} \pm$ S.D.) \\
\hline Water surface & 0 & 0 & -- \\
Water line & 0 & 0 & -- \\
Wet or moist soil & 2 & 0.1 & 1.5 \\
Dry soil & 15 & 0.7 & $3.9 \pm 2$ \\
\hline
\end{tabular}

$N=21$ habitat days; 15 habitat days were full sun.

Mortality profiles in the current study using An. gambiae eggs strongly resemble these carefully quantified proteindenaturation profiles from in vivo and in vitro preparations using cell lines and proteins from organisms not known to be selected for high thermal tolerance. Such similarities
Day 1
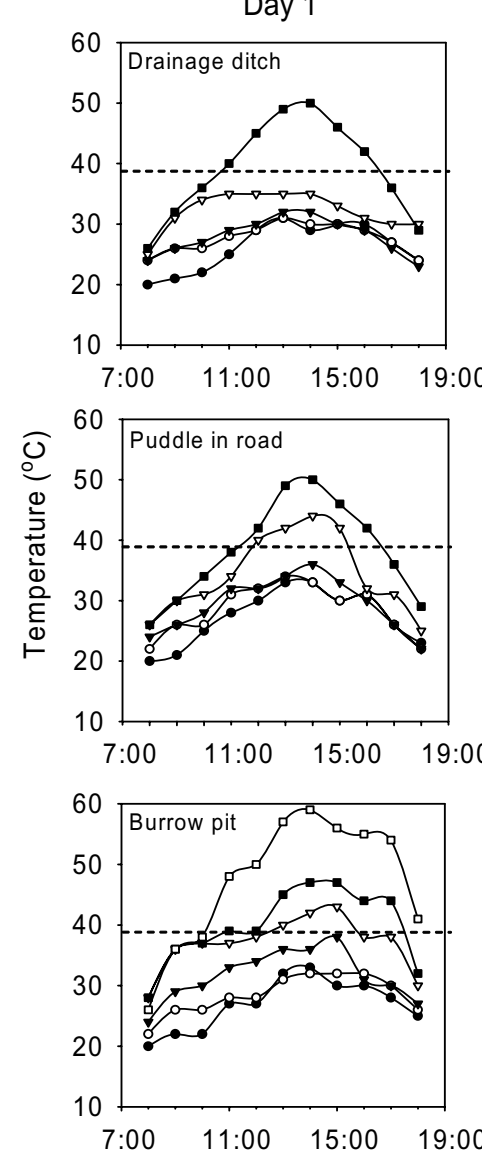
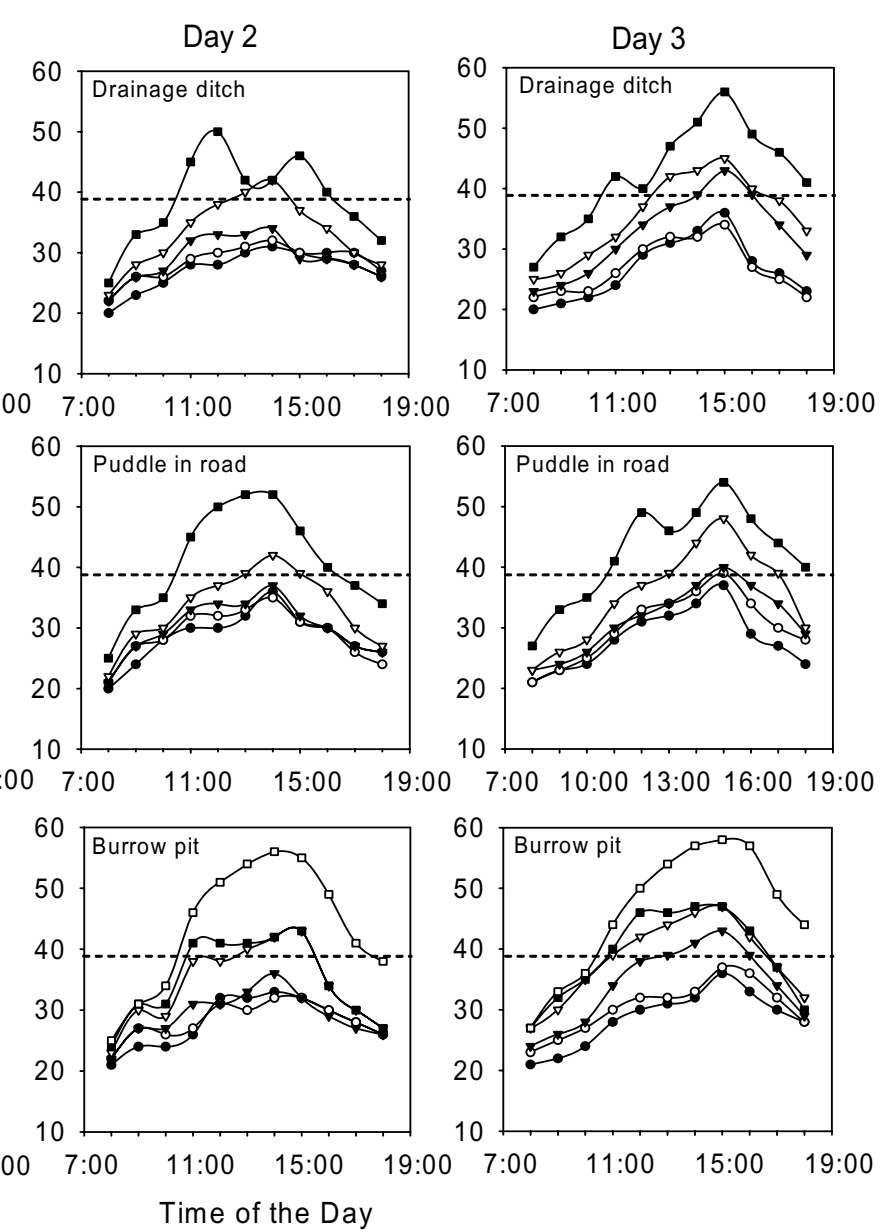

$\rightarrow-$ dry soil
$\rightarrow-$ wet-dry mud line

$$
\begin{array}{ll}
\longrightarrow- & \text { wet mud } \\
-\mathrm{-} & \text { water line }
\end{array}
$$$$
\begin{aligned}
& - \text { water surface } \\
& -\square-\text { dry rock }
\end{aligned}
$$

\section{Figure 5}

Daily temperature profiles in and around three typical types of Anopheles gambiae larval habitats on three consecutive days (May I 0, I I, and I2, 2005). The dotted line represents the upper tolerable temperature (40 $\left.{ }^{\circ} \mathrm{C}\right)$. Profiles recorded at similar sites on 4 other days were very similar. Table I reports outcomes across all the data. 
suggest An. gambiae is not uniquely adapted to tolerate temperatures above those lethal to animal cells generally.

Ability to tolerate high temperatures can vary with life stage. Results from the current study combined with the findings of Bayoh and Lindsay [12] reveal that An. gambiae eggs are the most $\left(40^{\circ} \mathrm{C}\right)$ and pupae and the $4^{\text {th }}$ instars the least $\left(34^{\circ} \mathrm{C}\right)$ heat-tolerant life stages, respectively. Notably, the temperatures within our puddles sometimes exceeded the tolerance limits for larvae and pupae as measured under a constant-temperature rearing regimes [12]. Munga et al. [23] reported that the mean maximum daily water temperature in puddle habitats in open farmland was $38.8 \pm 0.3^{\circ} \mathrm{C}$. In the current study, that value was $31.3 \pm 0.8^{\circ} \mathrm{C}($ mean \pm SEM $)$. Although daily temperature profiles in and around these larval habitats were measured only for 7 days, data collected at a weather station [24] indicated that the mean air temperature was very stable throughout all of 2005. Further research is justified to document to what extent Anopheles gambiae adult production is limited by maximal temperatures within puddles.

Eggs from the laboratory strain were slightly more sensitive to heat stress than eggs from house-collected mosquitoes. Perhaps rearing for more than five years under no thermal stress caused the laboratory strain to lose a bit of thermal tolerance. Enhanced thermal tolerance of individual insects following non-lethal heat shock has been reported in some insects $[8,25,26]$, including anopheline mosquito [26]. The effect of inducing heat-shock proteins in larvae of Anopheles albimanus was to increase the upper tolerable temperature by only $1.5^{\circ} \mathrm{C}$. Thermal conditioning in An. gambiae eggs and interaction of temperature with humidity are worthy of additional investigation.

An. gambiae eggs appear to be thermally adapted only to residing on water or moist mud. Rapid evaporation of water from mud apparently has a pronounced cooling effect, making mud not much different thermally from water (Figure 5). Perhaps this is why An. gambiae readily oviposit on moist or wet soil [2]. However, sun-exposed dry soil is inhospitable to these eggs because it readily exceeds lethal temperatures. Eggs on the surface of dry soils baked for several hours under full sun will not survive and thus cannot contribute to An. gambiae populations and malaria transmission.

\section{Authors' contributions}

JH and JRM designed and carried out the experiments, analysed and interpreted data, as well as drafted and revised the manuscript. EDW was P. I. of the grant supporting this work; he participated in study design, data interpretation, and revision of the manuscript. JV provided institutional support for this study. All authors read and approved the final manuscript.

\section{Acknowledgements}

The authors thank Joseph Nduati (Kenya Medial Research Institute (KEMRI), Kisumu, Kenya) for PCR species identification. The authors greatly acknowledge assistance with daily temperature measurement by Charles Ochieng and Geraldine Mwende (Kisian, Kenya). The authors also thank Piera Siegert, Bill Morgan, and Blair Bullard (Michigan State University) for technical assistance. This study was funded by National Institute of Health grant AI50703.

\section{References}

I. World Health Organization Expert Committee on Malaria: Twentieth Report. Geneva 2000.

2. Miller JR, Huang J, Vulule J, Walker ED: Life on the edge: African malaria mosquito larvae (Anopheles gambiae) are amphibious. Naturwissenschaften 2006 in press.

3. Huang J, Miller JR, Chen S-C, Vulule J, Walker ED: Anopheles gambiae (Diptera : Culicidae) oviposition in response to agarose media and cultured bacterial volatiles. J Med Entomol 2005, 43:498-504.

4. Koenraadt CJM, Paaijmans KP, Githeko AK, Knols BGJ, Takken W: Egg hatching, larval movement and larval survival of the malaria vector Anopheles gambiae in desiccating environments. Malar J 2003, 2:20.

5. Clements AN: The Biology of Mosquitoes. CABI Publishing, UK; 1999.

6. Beier JC, Copeland R, Oyaro C, Masinya A, Odago WO, Oduor S, Koech DK, Roberts CR: Anopheles gambiae complex egg-stage survival in dry soil from larval development sites in Western Kenya. J Am Mosq Control Assoc 1990, 6: 105-109.

7. Lapointe SL: Effect of temperature on egg development of Diaprepes abbreviatus (Coleoptera: Curculionidae). Florida Entomol 200I, 84:298-299.

8. Waddell BC, Jones VM, Petry RJ, Sales F, Paulaud D, Maindonald JH, Laidlaw WG: Thermal conditioning in Bactrocera tryoni eggs (Diptera: Tephritidae) following hot-water immersion. Postharvest Biol Tech 2000, 2 I: I I3-128.

9. Trpiš M, Haufe WO, Shemanchuk JA: Embryonic development of Aedes (O.) structys (Diptera: Culicidae) in relation to different constant temperatures. Can Ent 1973, 105:43-50.

10. Rayha $E$, Groun NAA: Effect of temperature on hatching eggs and embryonic survival in the mosquito Culex quinquefasciatus. Entomologia Experimentalis et Applicata 1983, 33:349-35I.

II. van der Linde TCK, Hewitt PH, Nel A, van der Westhuizen MC: Development rates and percentage hatching of Culex theileri Theobald (Diptera: Culicidae) eggs at various temperatures. J Entomol Soc Southern Africa 1990, 53:17-26.

12. Bayoh MN, Lindsay SW: Effect of temperature on the development of the aquatic stages of Anopheles gambiae sensu stricto (Diptera: Culicidae). Bull Entomol Res 2003, 93:375-38I.

13. Scott JA, Brogdon WG, Collins FH: Identification of single specimens of the Anopheles gambiae complex by the polymerase chain reaction. Amer J Trop Med Hyg 1993, 49:520-529.

14. Pervez OA: Temperature-dependent development and immature survival of an aphidophagous ladybeetle, Propylea dissecta (Mulsant). Jen 2004, I 28:5 I0-5 |4.

15. Beckett SJ, Morton R: The mortality of three species of Psocoptera, liposcelis bostrychophila Badonnel, Liposcelis decolor Pearman and Liposcelis paeta Pearman, at moderately elevated temperatures. Journal of Stored Products Research 2003, 39:103-115.

16. Mutuku FMM, Bayoh N, Gimnig JE, Vulule JM, Kamau L, Walker ED, Kabiru EW, Hawley WA: Pupal habitat productivity of Anopheles gambiae complex mosquitoes in a rural village in western Kenya. Amer J Trop Med Hyg 2006, 74:54-6I.

17. SAS Institute: Guide for personal computers, Version 6. SAS Institute, Cary, NC; 1999.

18. Beier MS, Beier JC, Merdan AA, Sawaf BME, Kadder MA: Laboratory rearing techniques and adult life table parameters for Anopheles sergentii from Egypt. J Am Mosq Control Assoc 1987, 3:266-270.

19. Jang EB, Nagata JT, Chan HT Jr, Laidlaw WG: Thermal death kinetics in eggs and larvae of Bactrocera latifrons (Diptera: Tephritidae) and comparative thermotolerance to three 
other Tephritid fruit fly species in Hawaii. J Econ Entomol 1999 , 92:684-690.

20. Jones SR, Kunz SE: Upper thermal limits for Hypoderma lineatum (Diptera: Oestridae) egg hatching and development. J Med Entomol 1997, 34:517-520.

21. Karter AJ, Folstad I, Anderson JR: Abiotic factors influencing embryonic development, egg hatching, and larval orientation in the reindeer warble fly, Hypoderma tarandi. Med Vet Entomol 1992, 6:355-362.

22. Nguyen VT, Morange M, Bensaude O: Protein denaturation during heat shock and related stress. I Biol Chem 1989, 264: 10487-10492.

23. Munga S, Minakawa N, Zhou G, Barrack OJ, Githeko AK, Yan GY: Oviposition site preference and egg hatchability of Anopheles gambiae: effect of land cover types. J Med Entomol 2005, 42:993-997.

24. BBC Weather [http://www.bbc.co.uk/weather/world/city guides/ results.shtml?tt=TT000280]

25. Beckett SJ, Evans DE: The effects of thermal acclimation on immature mortality in the Queensland fruit fly Bactrocera tryoni and the light brown apple moth Epiphyas postivttana at a lethal temperature. Entomologia Experimentalis et Applicata 1997, 82:45-5I.

26. Benedict MQ, Cockburn AF, Seawright JA: Heat-shock mortality and induced thermotolerance in larvae of the mosquito Anopheles albimanus. J Am Mosq Control Assoc 199I, 7:547-550.

Publish with Bio Med Central and every scientist can read your work free of charge

"BioMed Central will be the most significant development for disseminating the results of biomedical research in our lifetime. "

Sir Paul Nurse, Cancer Research UK

Your research papers will be:

- available free of charge to the entire biomedical community

- peer reviewed and published immediately upon acceptance

- cited in PubMed and archived on PubMed Central

- yours - you keep the copyright

Submit your manuscript here:

http://www.biomedcentral.com/info/publishing_adv.asp
BiolMedcentral 